\title{
Green Economy through Edification: Quality Life through Arts
}

\section{Akbar Nikkhah* \\ Chief Highly Distinguished Professor, Department of Animal Sciences, Faculty of Agricultural Sciences, University of Zanjan, Zanjan $313-45195$ Iran}

*Corresponding author: Akbar Nikkhah, Chief Highly Distinguished Professor, Department of Animal Sciences, Faculty of Agricultural Sciences, University of Zanjan, Zanjan 313-45195 Iran, Tel: 0098-241515280; E-mail: anikkha@yahoo.com

Rec Date: Sep 22 2014; Acc Date: Sep 25 2014; Pub Date: Oct 22014

Copyright: $\odot 2014$ Nikkhah A. This is an open-access article distributed under the terms of the Creative Commons Attribution License, which permits unrestricted use distribution, and reproduction in any medium, provided the original author and source are credited.

\section{Editorial}

The objective of this editorial article is to establish and delineate artistic strategic foundations for green economy [1,2] (GE)'s science and technology (SciTech) edification in the postmodern era. Green economy's SciTech edification is described and analyzed within an arts framework to reveal how strategic GE edification policies will become the postmodern scientific arts.

Edification bases GE and is highly considered as a multidisciplinary art. Arts are the means whereby human communicates with nature and environment. Postmodern life quality depends on GE edification quality. Policy-making in SciTech edification is key to timely human developments. Owing to the increasing importance of sufficient investments in GE edification, the economy balance must concentrate on multidisciplinary accomplishment. Green growth forms the core of GE. Green growth consists of climatic mitigation and adaptation policies, optimum carbon growth, ecosystem resilience, economic and equitable growth, biodiversity, and social development and poverty reduction. Special care must be given to interfiled co-operations.

The word 'arts' is a more-inclusive expression than 'art', which usually refers to visual arts. The arts encompass visual arts, literary arts, and the performing arts including music, theatre, dance and film, among others. The word 'arts' is described as imaginative, creative, and non-science senses and data that may be studied academically. Art is born when an artist creates an inspiring object, sense, science, or experience that has artistic merits. The artwork or the piece of art is analyzed and scored by experts and is most practically appreciated, assimilated, and enjoyed by spectators, viewers and listeners. Art is a global activity that hosts several disciplines, including Fine Arts, Liberal Arts, Visual Arts, Decorative Arts, Applied Arts, Design, Crafts, Performing Arts, and others. Arts are the means that man utilizes to communicate with surrounding nature and environment more insightfully. This suggests that arts can make GE science more understandable for green societies that pursue pleasure and quality in a sociable environment and life.

Artistic GE SciTech edification requires green environmentalist educators who can perceive, perform and analyze arts. Human brain is kinetically incomplete unless equipped with arts. Green economy scientists are analytical thinkers who exceptionally contemplate. Arts greatly help maintain quality thoughts and minds. Green SciTech edification must be inspired by professional arts training. Interactions among green arts and green science mentors will be synergistically beneficial. With artistic mentoring, GE mentees will experience joy and accomplishment in learning and teaching green SciTech. As a result of art-founded GE mentorship, a variety of green sciences can be advanced devotedly. Finest harmonies can be secured by educating a multitude of sciences as is rousing a piece of music by composing manifold melodies. Green sciences educated artistically will generate mentors being cognizant of the roles of green arts in quality new millennium green economy and SciTech edification $[3,4]$.

Ease and pleasure in mentoring green science and GE can be acquired with multi-science training. Basic sciences of mainly mathematics, physics and chemistry fit into applied sciences such as environment, ecology, economy, nutrition, medicine, and engineering. Advocating sciences apart in 'green science edification' should not be pursued. Capable artists often possess skills in complementary arts. Green SciTech and GE must yet learn from arts. Green SciTech transformation into green arts can optimize GE edification. Green SciTech edification policies will see arts as models to accomplish harmony. Green arts will help bridge among multiple green SciTech for GE. Green science will generate innovative perspectives to expand GE for quality environment and life.

Green SciTech edification [5] of the new millennium will be integrated with green arts. Social GE edification is how postmodern life generates merit. Green SciTech edification is a multidisciplinary art that enables human to communicate safely with nature and environment. To conclude, models from green arts will make life more understandable, more gratifying, and healthier. Green arts will inspire strong connections between green scientists and green societies. Green SciTech edification of the public should be accomplished artistically to boost GE for quality life in the new millennium.

\section{Acknowledgement}

Thanks to the Ministry of Science, Research and Technology, and University of Zanjan, Iran, for supporting the author's programs of optimizing the new millennium SciTech edification.

\section{References}

1. Mendonça M, Jacobs D, Sovacool BK (2010) Powering the green economy: The feed-in tariff handbook. World Future Council, London, UK.

2. Nikkhah A (2014) Timely Economy Evolution via Moral Science Edification. J Glob Econ.

3. Nikkhah A (2012) Structuring Science Education in the New Millennium: Authorizing a Succeeding Integrity. Nova Publishers Inc., NY, USA 28: 171-176.

4. Nikkhah A (2011) Science education of the new millennium: mentorship arts for creative lives. Creative Education 2: 341-345.

5. Pearce D (2013) Blueprint 2: greening the world economy. Earthscan, Taylor \& Francis Group, NY, USA. 